\section{$1 \mathrm{G} 1445$}

\section{ラット海馬神経回路特性の可塑性を光学的に測定する}

○冨永貫志、富永洋子、市川 道教（理研・脳センター・脳 㓱成デバイス)

中枢神経系における記憶・学習に挏いて、Hebb則に基づくシナプス 可塑性が重要であることは広く受け入れられている。これは実験的 には海馬のCA1 野に㧈けるシナブスの長期增強 (LTP)にも見ること が出来る。すなわち、CA1 野の主入力経路（シャーファー側枝）に 高頻度刺激 (HFS) などを与えると、刺激に対する入力一出力関係が 変化する。これは細胞レベル、サブ細胞レベルで確かめられた事実で ある。この個々の細胞の入・出力関倸の変化がそのまま線形に回路全 体での入・出力関倸に反映されるか㫘かは、问路特性の可塑性を知る 上で重要である。我々は海馬スライス標本を膜電位感受性色素で染色 し、光学的に神経回路の活動を測定することにより、この点を追求し ようとしている。この方法により、局所神経回路の各部位ごとの入． 出力関係を大局的に測定できることを今回の発表の主題とした。我々 は、刺激強度を変え回路全体の活動伝播を測定し、約 25 ミクロン四 方のコンパートメント (ピクセル) 毎の CA1 野神経組織（視野は扩 よそ $1.3 \times 2 \mathrm{~mm})$ の入・出力関係を得た。個々の入・出力関倸は $\mathrm{S}$ 字 関数で表されたので、その経験式を使って個々の部位での反応の最大 值、半值刺激值、刺激に対する感受性を出し、それらのパラメータが LTPの誘導によってどのように変わるかを評価した。一般にもっとも よく用いられているLTP 誘導刺激である HFSを加えたときには、は とんどのコンパートメントにおいて半值刺激值の滅少が顕著に見られ たが、その変化の度合いは刺激点よりも遠い部位に顕著であった。こ れは、見かけ上はHeb則からの逸脱、すなわち、もっとも出力の小 さかった細胞群がより大きく変化していることを示している。一方、 個々の細胞における興奮・出力関係の変化も示すことができた。

T. Tominaga, Y.Tominaga and M.Ichikawa : Plasticity of neural circuit in rat hippocampal slice quantified with optical recording method

\section{$1 \mathrm{G} 1515$}

小脳プルキンエ細胞の非電気的シナプス統合に対す るマルチコンパートモデルを用いたシミュレーショ ン解析

○長野浩治 ${ }^{1}$ 、高木 博 ${ }^{2}$ 、伊藤 悦朗 ${ }^{1}$ ( 1 北大·院理・生物科 学、2 信州大·医・神経可塑性分野)

近年, プルキンエ細胞において古典的な電気的シナプス統合とは異 なる「非電気的シナブス統合」が，神経細胞で生じているという報告 が提出された。これらの報告によると，闒值以下でのシナプス刺激に より， $\mathrm{Ca}^{2+}$ の局所的な流入がスパインや近隣の微細樹状突起などの 限られた部位で起こっており，それが非電気的シナプス統合過程にお いて重要な役割を果たしているらしい。

本研究では, 非電気的シナプス統合機構において重要な要素の一つで ある細胞内 $\mathrm{Ca}^{2+}$ 濃度上昇に注目し、コンピュータ・シミュレーショ ンにより各種チャネルの性筫・細胞膜の性質・イオンの細胞内外間の 膜透過性を考虑しながら，微練樹状突起での局所的な $\mathrm{Ca}^{2+}$ 流入の寒 駼結果の再現掞よびそれらの詳細な時間的 $\mathrm{Ca}^{2+}$ 濃度変化の解析を行 なうことを目的とした。

今回は, シミュレーション・ソフトゥエアとして NEURON (version 4.2.1) (M.L.Hines et al. Neural Comput. (1997) 9: 1179-1209) を使 用し，プルキンエ細胞のモデルは D.P. Shelton (Neuroscience. (1985) 14: 111-131) を参考にし, 計 1089 個からなるマルチコンパートメン トモデルを構築した。プルキンエ細胞に存在する各種チャネルをモデ ル化し，細胞モデルに導入した結果，局所的シナプス刺激では $\mathrm{Ca}^{2+}$ 濃度上昇が微細樹状突起の限られた部位で生じ，近傍ではほとんど生 じないことを確認できた。この結果から，樹状突起とスパインが存在 寸る微細街上突起には, 各種チャンネルの分布に違いがあることが示 唆された。また，実験では検出不可能な高時間分解能の細胞内 $\mathrm{Ca}^{2+}$ 動態変化を明らかにできた。

K.Chono, H.Takagi and E.Ito : Simulation analysis of non-electrica synaptic: integration in cerebellar Purkinje cell using a multicompartment model

\section{$1 \mathrm{G} 1500$}

\section{瞬目反射条件付けにおける小脳LTDの役割（2）NO} 合成阻害の効果

○鈴木 成教. 川原 茂敬, 桐野 豊 (東大·院真·神経生物物理)

【目的】瞬目反射条件付けは、音（条件刺激、CS）と瞼への刺激（無 条件刺激、US）を組合わせて繰り返し提示することにより、音孛聞 いただけで瞬きを行うようになる学㥜である。この学習は小脳連動 学習の1つとして知られ、小脳皮質の長期㧕压（LTD）を神経基盤 とする回路モデルが提案さ机ている。しかしながら、我々は、小脳 LTDに障害をもつグルタミン酸受容体サブタイプ（GhR）。損マ ウスを用いて、CSとUSが時間的に重なる場合には学留が障害され るが重ならない場合には障害されないことを見いだし、前年会までに 報告してきた。本年会では、同様に小脳LTDに障害を持つ一酸化窒 素 (NO) 合成酵素 (nNOS) 欠損マウス、及び、NO合成酵素阻害薬 （L-NAME）を小脳内投与したマウスを用いて、瞬目反射条件付けに 扔ける小脳 LTDの役割を検討した。【方法】マウス（C57BL/6.J）を 用いて、US $(100 \mathrm{~Hz} 、 100 \mathrm{~ms})$ が CS $(1 \mathrm{kHz} 、 90 \mathrm{~dB} 、 352 \mathrm{~ms})$ に荤 れて開始し同時に終了する課題、又は CS 終了直後にUSが始まる課 題を 1 日 100 回（50分間）行った。薬物投与では、条件付け開始 20 分前に L-NAME、生理食塩水、又はD-NAMEをカニューレを用いて 小脳内投与（15 mM、0.5 ml）した。【結果・考察】CS-USの重なり が無い場合には、nNOS 欠損マウス及び L-NAMEを投与したマウス 共にコントロールと同様の学習が認められた。また、CS と USが重 なる課題では、L-NAMEにより学習が著しく障害された（nNOS欠 損マウスについては現在行っている)。以上の結果は CS-USの重なり が無い場合には、NOそして小脳LTDは学習には必ずしも必要でな いことを示している。一方、CS-US の重なりがある場合には小脳の NOが必要であり、従来の小脳LTD 依存モデルを支持している。

M.Suzuki, S.Kawahara and Y.Kirino: The role of cerebellar LTD in eyeblink conditioning (2) : the effects of NO synthesis inhibition

\section{$1 \mathrm{G} 1530$}

\author{
脳とはどんなコンピュータか
}

松本 元 (理研·脳総研)

生体情報処理システムは、情報に対寸る開放系の科学として捉える ことができ、遺伝情報システムや脸・免疫、さらに社会環境と階層化 される。脳の目的は、情報を選択し、その選択した情報の処理の仕方 を獲得することである。この目的の達成の為に、脳の情報原理がメモ リー主体方式であること、脳の構成原理が時系列情報を連合する出力 依存性学習と一度長期記憶として獲得した情報処理の仕組みは、生 涯に自って消去されず、追加学習的に階層構造化されることである。 脳の目的・原理を具体的に表現する為に、脳は目標を設定しその最も 上位の目標に対する限りない愛によって、その目標を達成する仕組み を獲得する方向に向加う。脳の目的に沿って生きる時、人は輝く。 脳は情報を処理する為の代組み(アルゴリズム)を自ら獲得すること が目的である。この為に、まず何の情報のアルゴリズムを獲得する かが無くてはならないので、情報をも自ら選択する。すなわち、脳仗 自ら選択した情報のアルゴリズムを自分で創り出すことを目的とし たシステムである。この事を目的とした情報処理システムを脳型コ ンピュータと言う。これに対し、従来型のコンピュータでは、情報の 選択とその情報の処理の仕方は、プログラムとして人より与えられ、 入力情報を処理する為の手段である。つまり、得た入力情報を、プロ グラムが処理し、出力することが目的である。この立場から、脳と コンと゚ュータの本質的違いは、目的と手段が丁度入れ替わっていると いうことにある。そこで、脳はどの様に自ら情報を選択するかを明ら かにすること、更にその設定した情報処理の仕組みをいかに獲得する か、などについて述べる。 